\title{
Mispronouncing of Consonant Alveolar Plosive/t/, and /d/ in The Final position in English byTarakanese
}

\author{
Fithrah Auliya Ansar', DarwissyahIrwan Duhir² \\ ${ }^{1}$ Department of English Education, Faculty of Tarbiyah and Teaching Training \\ UIN RadenIntan Lampung, Sukarame 35131, Bandar Lampung, Indonesia \\ ${ }^{2}$ Department of English Education, Faculty of Social and Humanities \\ UNU Lampung, Sukadana 34194, East Lampung Regency, Indonesia \\ *Corresponding Author: \\ Email: fitrahauliyaansar@,radenintan.ac.id
}

\begin{abstract}
:
This study aims to examine whether speakers who have a basic English language make mistakes in pronouncing the plosive / $t /, / d /$ consonants due to the influence of the Tarakan language, which is the language of the speakers during their domicile in the area. A recording technique was used in collecting data. The instrument used is a list of words, sentences and paragraphs. The population in this study were English-bachelor students who had lived in Tarakan for a long time and were accustomed to using the Tarakan accent. The sampling technique used was purposive sample of 3 people. Data were analyzed using descriptive qualitative methods by analyzing the data of the transcription. The results of this study indicate that in pronouncing English consonants and vowels, there are still many students who do not pronounce them correctly. They make a lot of mistakes in pronouncing the plosive / $d /$ correctly in every word. They tend to change it to $/ \mathrm{t} /$.

Keywords: Interlanguage, Pronunciation, Plosive /t/ and /d/, Tarakanese
\end{abstract}

\section{INTRODUCTION}

Language plays an important role in human life. Through the language, people can communicate what they want to convey both ideas and feelings. It is a tool of communication. Languages have different accents. Everyone has different way to pronounce the word. They pronounce language differently depends on the geographical places of the person or social classes of the person. Most the people in this world live with the desire to know one or more foreign language. However, most people think that learning foreign language is better than learning our mother tongue. It is because learning mother tongue can come naturally. There are many international languages in this world but one of them, which is very popular in this world instead of Arabic, is English.

English is the most familiar and popular language in this world. English is used by many countries as a national language and as an international language. However, only some non-native speakers can pronounce English correctly. It happens because we come from many different backgrounds and environment. Environment also can influence us the way to speak with others not only the accent but also the dialect. Many people speak English as their own way to pronounce it. But the problem is it can make miss interpretation of the hearer. The understanding of the words enables people to have good communication. That is why the important of us to study about producing sounds. It can help the speaker 
to pronounce the word correctly. Phonology has to do with the rules and patterns of sounds in a language. The discipline of linguistics is concerned with describing how the people pronounce when they know the language, this knowledge is very complex, and largely unconscious; because in one district even has a same mother tongue, the society may have different way to pronounce something. The social class and educational background can possibly interfere the language features of the speaker. A problem area that has received a lot of attention is the choice of symbols for representing English phonemes. In learning English, learner must concern with the phoneme, which is the basic of the study.

The speakers of English must aware of the syllables of sounds, but sometimes the speakers can make mistake in pronouncing the phoneme of the word because not too extremely giving attention of the phonemes. Speaker must realize the way to pronounce English. Misunderstanding and misinterpretation can happen if the speaker make the mistakes in pronouncing accidentally. So that second language learners need to learn the way to communicate with others by using the correct phonemes, although speakers may not be aware of their feature's consciousness, they are linguistically significant.

Based on the explanation above, the writer is concerning on the interlanguage in Tarakan people utterance especially in Tarakan people. The writer has some items of problem to be analyzed, which have been formulated into questions: How do the Tarakan people pronounce English consonant; and what kind of mistakes that Tarakan people do in pronouncing English? This research provides information and suggestions of the usages of English as a foreign language in the utterance. In addition, the writer hopes there will not misinterpretation of some utterances by the hearer in doing communication with Tarakan people because of faulty pronouncing words especially in pronouncing consonants plosive /t/, /d/.

Studies about English pronunciation has been becoming an interesting issue in language studies from normal participants to repaired cleft lip and palate (Zajac et al. 2013). Therefore, many studies has been conducted to examine English pronunciation. Specifically, study about pronunciation error and difficulties has been attracting many researchers throughout the world. Research regarding the influence of L1 as encountered by English learner from Arab (Alzinaidi\&Ahmad, 2019) and in air-traffic communication in Korea (Kim \&Billington, 2018). Binturki (2008) also demonstrated that Saudi English Learner had difficulties to pronounce voiced interdental fricative $/ \mathrm{V} /$ and to reduce extent of $/ \mathrm{p} /$ and $/ \mathrm{x} /$. Likewise, Vietnamese mispronouncing English consonant (Nguyen, 2007). Turkish phonology system affected English learners in Turkey (Varol, 2012). Those researchers assigned that non-Native English learners encountered difficulties pronouncing English phonetics because of the influence of L1 phonetic and pronunciation systems, which differed from English. Moreover, strong Swedish accent interfered students in their English pronunciation (Centerman \&Krausz, 2011); English learners from Czech also had difficulties with English pronunciation (Ambrozova, 2014); Mustapha \&Ishaku (2020) found that Nigerian was confused between Nigerian and English phonetic systems that made them mispronouncing English words. All of them discovered that influence of L1 phonetic system and pronunciation became the major factor of English miss-pronunciation encountered by people from different countries.

Investigations concerning Indonesian English learners also has been conducted since long years ago, such as Ingrid Mathew (1997) examined pronunciation errors of Indonesian on final stops, sibilant and final affricates and interdentals. Yet, the study was not too specific mentioning particular sounds. Furthermore, many recent studies observe English pronunciation error specifically, such as Sakul (2013); Syuhadi (2014); Rifqi (2015); Azlina (2016); Wulansari (2017); Arafiq et al (2019); Ardini (2019); Wafi et al (2020) and Hadroh (2020).

$\underline{\text { http://ijstm.inarah.co.id }}$ 
Every local language has their own accents, phonetics and pronunciation systems that influence their way of speaking in English. Therefore, this study examines specifically on consonant plosive /t/ and /d/ to enrich linguistics study about pronunciation error.

\section{RESEARCH METHODS}

The method used in this research has been qualitative method. Qualitative method is a method that is intended to collect the data and analyze the data which used the theory related to the subject research. The population of this research is the eight semester students of English Literature Department of Adab and Humanities Faculty of Alauddin State Islamic University of Makassar. This research used purposive sampling method that engaged of 3 students as the object of data sampling. All the studentsare Tarakanese. They are from Tarakan and migrate to South Sulawesi due to their academic studies.Most of them indicates special characteristics in speaking English.

Table 1.1 English Consonant of RP and GA (Gut, 2009)

\begin{tabular}{ccc}
\hline Phonetic symbol & \multicolumn{2}{c}{ Examples } \\
\hline & word-initial & word-final \\
$\mathrm{p}$ & pin & rip \\
$\mathrm{b}$ & bin & rib \\
$\mathrm{t}$ & tin & sit \\
$\mathrm{d}$ & din & rid \\
$\mathrm{k}$ & kin & Rick \\
$\mathrm{g}$ & go & rig \\
$\mathrm{m}$ & mine & rim \\
$\mathrm{n}$ & nine & Rhine \\
$\mathrm{j}$ & - & ring \\
$\mathrm{f}$ & fin & riff \\
$\mathrm{v}$ & vase & live \\
$\theta$ & thin & heath \\
$\mathrm{o}$ & this & with \\
$\mathrm{s}$ & sin & rice \\
$\mathrm{z}$ & zoo & rise \\
$\mathrm{f}$ & shin & wish \\
3 & genre & beige \\
$\mathrm{h}$ & him & - \\
$\mathrm{l}$ & rim & beer \\
$\mathrm{j}$ & & (GA only) \\
$\mathrm{I}$ & year & -- \\
$\mathrm{w}$ & Lynn & bile \\
$\mathrm{t}$ & whim & -- \\
$\mathrm{d} 3$ & chin & hatch \\
& gin & lodge \\
\hline & &
\end{tabular}

The table of English consonant above is an overview of English consonant. Further, to define English consonant can be done by determining its place of articulation. O'Grady, William, John Archibald, and Mark Aronoff. et al., (1989): Jones (1972) and Sembiring\& Fiber (2016) in Wafi et al (2020) categorized the places of articulation such as: bilabial, labio-dental, dental, alveolar, alveopalatal or palate alveolar, palatal, velar, labio-velar, retroflex, and glottal. Alveolar sounds are sounds produced by the tip or blade of the tongue against the teeth-ridge. The sounds are $/ \mathrm{t} /, / \mathrm{d} /, / \mathrm{s} /, / \mathrm{z} /, / 1 /, / \mathrm{n} /$. Specifically in this study, concerned-alveolar consonants were merely /t/ and /d/. Moreover, defining consonant can be done by identifying the way of its articulation, known as manner of articulation. It is divided into Plosive, Fricative, Affricates, Nasal and Liquid or Lateral. Plosive / stops: sounds formed by completely closing the air passage through the oral cavity and suddenly removing the obstacle, so that the air escapes making 
an explosive sound. The sounds are $/ \mathrm{p} / / \mathrm{b} /, / \mathrm{t} / / \mathrm{d} /, / \mathrm{k} / / \mathrm{g} /, / \mathrm{z} /$. In this study, the focused-plosive sound were $/ \mathrm{t} /$ and $/ \mathrm{d} /$. There are three components used in analyzing the data, they are words, sentences and paragraphs. Recording was used in collecting the lists of data. However, the identificationof pronunciation process was highlighted specifically to alveolar plosive $/ \mathrm{t} /$, and /d/ at the end of a word made into statistics' transcriptions. And the last discussing and summarizing the findings.

\section{FINDING AND ANALYSIS}

The findings are ordered in line with the problem statements outlined in the introduction part whereas in the analysis, arguments and further interpretation of the findings are given. There are also some discussions related to the result and other researches include in the elaboration of the data. There are three parts of data analyzed in this research. They are word lists, sentence list and paragraph list.

\section{a. Word list}

From the result of observation, the speakers actually can speak English well but because of English is our foreign language so that they cannot pronounce it correctly in a sentence or paragraph instead of the speaker has to aware the way they pronounce words. They felt hard to pronounce consonant alveolar plosive $/ \mathrm{t} /$, and /d/ at the end of a word. Therefore, so many mistakes they made when pronounce the word list. Their mother tongue may difficult to differentiate between $/ \mathrm{t} /$ and $/ \mathrm{d} / \mathrm{in}$ final position of the word. There are 20 words given to the speakers to pronounce.

Table 3.1. Students pronounce each given word

\begin{tabular}{|c|c|c|c|c|}
\hline \multirow[b]{2}{*}{ NO } & \multirow[b]{2}{*}{ WORDS } & \multicolumn{3}{|c|}{ THE SPEAKERS } \\
\hline & & SPEAKER 1 & SPEAKER 2 & SPEAKER 3 \\
\hline 1 & Add /æd/ & /əd/ & /əd/ & /æt / \\
\hline 2 & $\mathrm{At} / \mathrm{t} \mathrm{t} /$ & /ot/ & $/ \partial t /$ & $/ \partial t /$ \\
\hline 3 & lout/lavt/ & /lout / & /lout / & /lavt/ \\
\hline 4 & loud /lavd/ & /lout / & /lout / & /lavd/ \\
\hline 5 & Bleat/bli:t/ & /bli:t / & /blæd / & /bli:t / \\
\hline 6 & Bleed /bli:d/ & /bli;t/ & /bli:d/ & /bli:d/ \\
\hline 7 & $\mathrm{Bad} / \mathrm{bæd} /$ & /bæd / & /bæd/ & /bæd/ \\
\hline 8 & Bat /bæt/ & /bæt / & /bæt/ & /bæt/ \\
\hline 9 & Seed /si:d/ & /si:t/ & /si:d / & /si:t/ \\
\hline 10 & Seat/si:t/ & /si:t / & $/ \mathrm{si}: \mathrm{t} /$ & /si:t / \\
\hline 11 & Sat /sæt/ & $/ \mathrm{sæd} /$ & $/ \mathrm{sæd} /$ & /sæt/ \\
\hline 12 & $\mathrm{Sad} / \mathrm{sæd} /$ & $/ \mathrm{sæd} /$ & /sæd/ & $/ \mathrm{sæd} /$ \\
\hline 13 & Pat /pæt/ & /pæt/ & /pæt/ & /pæt/ \\
\hline 14 & $\mathrm{Pad} / \mathrm{pæd} /$ & /pæt/ & /pæd/ & $/ \mathrm{pæd} /$ \\
\hline 15 & Bet /bet/ & /bet/ & /bet/ & /bet/ \\
\hline 16 & Bed /bed/ & /bet/ & /bed/ & /bed/ \\
\hline 17 & Let /let/ & /let/ & /let/ & /let/ \\
\hline 18 & Led /led/ & /led/ & /led/ & /let/ \\
\hline 19 & Cart /ka:t/ & /ka:t/ & /ka:t/ & /ka:t/ \\
\hline 20 & Card /ka:d/ & /ka:t/ & /ka:d/ & /ka:d/ \\
\hline
\end{tabular}

There are 7 mistakes made by the Speaker 1 in pronouncing /t/ and /d/ in final position whereas Speaker 2 and 3 made only 3 mistakes in the data. However, most of them have different mistakes in pronouncing /t/ 
and $/ \mathrm{d} /$ in the words. The words that commonly showed the errors in the pronunciation of $/ \mathrm{t} / \mathrm{and} / \mathrm{d} / \mathrm{in}$ final position were loud, sit, and sad.

b. Sentence list Result

Table 3.2. The error pronouncing made by the sample of Tarakan people in pronouncing English

\begin{tabular}{|c|c|c|c|c|c|c|c|c|}
\hline \multirow[t]{2}{*}{ No } & \multirow[t]{2}{*}{ Consonant } & \multirow[t]{2}{*}{ Sentence } & \multicolumn{2}{|c|}{ Speaker 1} & \multicolumn{2}{|c|}{ Speaker 2} & \multicolumn{2}{|c|}{ Speaker 3} \\
\hline & & & True & False & True & False & True & False \\
\hline 1. & $/ \mathfrak{e d} /$ & $\begin{array}{l}\text { My professor asked me to } \\
\text { add some secondary data } \\
\text { in my study }\end{array}$ & & $\sqrt{ }$ & & $\sqrt{ }$ & & $\sqrt{ }$ \\
\hline 2. & /bæd/ & $\begin{array}{l}\text { Don't disturb him, I think } \\
\text { he is in a bad mood }\end{array}$ & $\sqrt{ }$ & & $\sqrt{ }$ & & $\sqrt{ }$ & \\
\hline 3. & /bli:d/ & $\begin{array}{l}\text { Everyone seems to bleed } \\
\text { for his misery }\end{array}$ & & $\sqrt{ }$ & & $\sqrt{ }$ & $\sqrt{ }$ & \\
\hline 4. & $/ \mathbf{s i}: \mathbf{d} /$ & $\begin{array}{l}\text { The seed should be kept } \\
\text { in a dry place }\end{array}$ & & $\sqrt{ }$ & & $\sqrt{ }$ & & $\sqrt{ }$ \\
\hline 5. & /pæd/ & $\begin{array}{l}\text { Could you please buy me } \\
\text { an ink pad when you go } \\
\text { out }\end{array}$ & & $\sqrt{ }$ & & $\sqrt{ }$ & & $\sqrt{ }$ \\
\hline 6. & /sæd/ & $\begin{array}{l}\text { He felt so sad when he } \\
\text { wasn't included in the } \\
\text { team }\end{array}$ & $\sqrt{ }$ & & $\sqrt{ }$ & & $\sqrt{ }$ & \\
\hline 7. & /bed/ & $\begin{array}{l}\text { I feel a bit dizzy, I went } \\
\text { to bed late last night }\end{array}$ & & $\sqrt{ }$ & $\sqrt{ }$ & & $\sqrt{ }$ & \\
\hline 8. & /led/ & $\begin{array}{l}\text { This path led us to the old } \\
\text { castle }\end{array}$ & & $\sqrt{ }$ & & $\sqrt{ }$ & & $\sqrt{ }$ \\
\hline 9. & /ka:d/ & $\begin{array}{l}\text { You need a special key } \\
\text { card to enter the } \\
\text { computer lab }\end{array}$ & & $\sqrt{ }$ & & $\sqrt{ }$ & $\sqrt{ }$ & \\
\hline 10. & loud /lavd/ & $\begin{array}{l}\text { Most people can't stand } \\
\text { with a loud music }\end{array}$ & $\sqrt{ }$ & & & $\sqrt{ }$ & $\sqrt{ }$ & \\
\hline
\end{tabular}

There are three sentences included as the data of this research. From the result, we may conclude that the speaker 1 and 2 made plethora mistakes in pronouncing the consonant in the sentences while speaker 3 only makes some mistakes. The intonation in pronouncing English among them also determines different voices.

\section{c. Paragraph list Result}

Table 3.3: the error pronouncing data in the paragraph

\begin{tabular}{|c|c|c|c|c|c|c|c|c|}
\hline \multirow[t]{2}{*}{ No } & \multirow[t]{2}{*}{ Consonant } & \multirow[t]{2}{*}{ Paragraph } & \multicolumn{2}{|c|}{ Speaker 1} & \multicolumn{2}{|c|}{ Speaker 2} & \multicolumn{2}{|c|}{$\begin{array}{c}\text { MareSpeaker } \\
\mathbf{3}\end{array}$} \\
\hline & & & True & False & True & False & True & False \\
\hline 1 & $\begin{array}{l}\text { Seed /si:d/ } \\
\text { Pad /pæd/ } \\
\text { Bed /bed/ } \\
\text { Sad /sæd/ } \\
\text { Led /led/ } \\
\mathrm{Bad} / \mathrm{bæd} /\end{array}$ & $\begin{array}{l}\text { In that day I decided to } \\
\text { seek john at his flat to } \\
\text { give him a moral support } \\
\text { for his misery. Before } \\
\text { getting to his flat, I } \\
\text { stooped at the }\end{array}$ & $\sqrt{ }$ & $\begin{array}{l}\sqrt{ } \\
\sqrt{ }\end{array}$ & $\sqrt{ }$ & $\begin{array}{l}\sqrt{ } \\
\sqrt{ }\end{array}$ & $\sqrt{ }$ & $\begin{array}{l}\sqrt{ } \\
\sqrt{ }\end{array}$ \\
\hline
\end{tabular}




\begin{tabular}{|c|c|c|c|c|c|c|}
\hline & & $\begin{array}{l}\text { supermarket near john's } \\
\text { flat to buy him some } \\
\text { apples and a Chinese } \\
\text { seed, and I also remember } \\
\text { to buy an ink pad and a } \\
\text { postcard for my flat mate, } \\
\text { rick. When I got there, I } \\
\text { found him just lying on } \\
\text { his bed. He looked so sad. } \\
\text { I was afraid this led him } \\
\text { to do a bad thing. }\end{array}$ & $\begin{array}{l}\sqrt{ } \\
\sqrt{ } \\
\sqrt{ }\end{array}$ & $\begin{array}{l}\sqrt{ } \\
\sqrt{ } \\
\sqrt{ }\end{array}$ & $\sqrt{ }$ & $\begin{array}{l}\sqrt{ } \\
\sqrt{ }\end{array}$ \\
\hline 2 & $\begin{array}{l}\text { Bleed /bli:d/ } \\
\text { loud /lavd/ } \\
\text { Add /æd/ }\end{array}$ & $\begin{array}{l}\text { Everyone in our class } \\
\text { seemed to bleed for his } \\
\text { misery. This condition } \\
\text { was even worsened by } \\
\text { the loud music from a } \\
\text { café near his flat. We had } \\
\text { chitchat and I tried to } \\
\text { make him happy and } \\
\text { escape from his misery. } \\
\text { When I was about to } \\
\text { leave, he asked me to add } \\
\text { some more water to his } \\
\text { glass. }\end{array}$ & $\sqrt{ }$ & $\sqrt{ }$ & $\sqrt{ }$ & $\sqrt{ }$ \\
\hline
\end{tabular}

The difficulties in pronouncing words which are consonant alveolar plosive /t/, and /d/ found at the end of a word in the sentence. Those three speakers made the errors inconsistencies. The speakers sometimes pronounce the words in a sentence but incorrectly in the paragraph. The speakers could directly pronounce the word properly if it is stand alone or separate with other words whereas if the words in the sentence or in paragraph, the speakers need a habitually in pronouncing the words correctly. For instance, Speaker 1 and Speaker 2 in pronouncing Led /led/; Both already said the word correctly but when the word came into the sentence or in paragraph, they pronounced Led differently. They said the word in the sentence incorrectly. Another sample of the data shows that in pronouncing Bad, all the speakers did the mistakes similarly. They can pronounce the word correctly if it is not bounded in sentence or paragraph.

Cultural interference may influence the way of the speakers in pronouncing words. In the data before we can observe that Speaker 1 and Speaker 2 almost have same way to pronounce something. It may happen because Speaker 1 and Speaker 2 are roommates. They lived in the same boarding house, so that they influence each other in pronouncing words. They communicate each other every day so they get use to speak as like as their roommate. Psychology also has a role in influencing people's pronunciation. According to the data of interview, the first speaker has made many errors in pronouncing consonant $/ \mathrm{t} /$ and $/ \mathrm{d} /$ because there is a pressure in pronouncing all of the words in the list, She tried to pronounce perfectly even she felt hard to get use with the phonemes of the words. Moreover, the speaker 1 is the first speaker who pronounces the words in the list. Different with speaker 1, speaker 2 and 3 pronounced the words better than first speaker because they already knew about the recording from the first speaker. From the data also shows that the closest relationship can influence someone's performance in pronouncing words. As many studies revealed that Indonesian English learner likely to have difficulties in english pronunciation because of different vowel and consonant phonetic systems between Indonesian and English, study in this problem is used to be fascinating. A study conducted by Hadroh (2020) found 
that at least there are eight English consonant that frequently mispronounced by Indonesian learners in Islamic Secondary school in Pasuruan. The consonant sounds such as "ch" [t], "y" [j], "th" [ð], "v" [v],

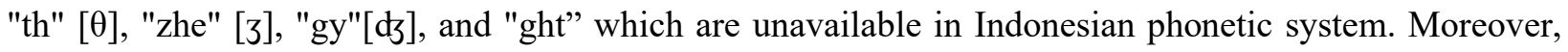
Arafiq et al (2019) found that Sasak, Bimanese, and Sumbawa students difficultly pronouncing /v/ and replacing it into $/ \mathrm{p} /$ instead. Beside, consonant alveolar plosive $/ \mathrm{t} / \mathrm{and} / \mathrm{d} / \mathrm{were}$ hard to pronounce. This study implies that mother tongue is crucial problem in English pronunciation learning in West Nusa Tenggara, Indonesia.

Indonesian is known as multi-lingual country. Although the Indonesian speak Indonesian language as their unity, people from different tribes, provinces and island speaks their own local language as their mother tongue. Therefore, many studies discovered similar difficulties in English learning as Foreign Language. For instance, mother tongue interference affected Madurese when learning English in Pare, Kediri - East Java (Rifqi, 2015). Moreover, a strong Javanese accent explicitly recognized from Joko Widodo, Indonesian $7^{\text {th }}$ president in his English speech, as examined by Azlina (2016).

Likewise, Wulansari (2017) discovered error pronunciation of University students in UIN SunanAmpel Surabaya. Although the students were in higher semester and the entire students from English department, the error pronunciation was still inevitable. Respectively, Ardini (2019) also proved that most of Javanese omitted English phonetic systems that were unavailable in Javanese phonetic system. The omitting phenomenon then called as phonological fossilization. The Javanese learners tend to

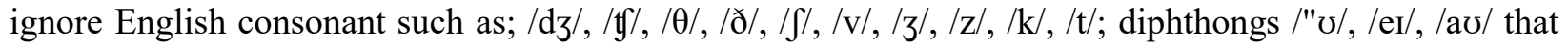
are influenced by their Javanese phonetic system. Similarly, people from Tarakan have difficulties to pronounce English. Tarakan is a region located in North Borneo province, Indonesia. The word "Tarakan" was derived from 2 words "Tarak" and "Ngakan" based on its historical background. The area was a prominent place for trading and tourism before Dutch Colonialization (Pasaribu, 2016).

\section{CONCLUSIONS}

Based on the observation the observation and analysis of the data, there are two points occur in the conclusions, they are:

1. The difficulties of Tarakanese in pronouncing words which are consonant alveolar plosive $/ \mathrm{t} /$, and /d/ in the final position mostly appeared in the paragraph structure, whereas the correct pronunciation is closely correct if the phoneme of those consonants $/ \mathrm{t} /$ and $/ \mathrm{d} /$ were located in the single word.

2. Environment and psychology can influence the way of the speaker pronouncing the words. The closest relationship can influence someone has similarity in pronouncing words; the mental conditions of the speaker also influence the speaker's pronunciation.

\section{ACKNOWLEDGEMENT}

The authors express their deepest gratitude to the Tarakan students' association at UIN Alauddin Makassar for supporting this project. We also thank to the students who were willing to be our sample. May this project can give a contribution of the language learning and research.

\section{REFERENCES}

[1] Alzinaidi, Mahanel Hamad; Latief, Muhammad Abdel. (2019). Diagnosing Saudi Students' English Consonant Pronunciation Errors. Arab World English Journal (AWEJ) Volume 10. Number 4 December 2019 Pp.180- 193. 
[2] Ambrozová, M. (2014). English Pronunciation difficulties among Czech students: Causes and compensation strategies. MA thesis, Faculty of Humanities, Tomas Bata University in Zlin, Czech Republic.

[3] Arafiq et al 2019. Mapping Students' Phonological Problems in Pronouncing English Sounds: A Study on Speakers of Local Languages in West Nusa Tenggara. Advances in Social Science, Education and Humanities Research, volume 465 (199-202) Proceedings of the 1st Annual Conference on Education and Social Sciences (ACCESS 2019)

[4] Ardini, Sukma Nur; Soenawarsito. (2019). Phonological Fossilization of EFL Learners: The Interference of Phonological and Orthographic System of L1 Javanese. 3L: The Southeast Asian Journal of English Language Studies. (25) 2: 74-85.

[5] Azlina (2016). An analysis of English Pronunciation errors of Joko Widodo's speech.

[6] Binturki, T. A. (2008). Analysis of pronunciation errors of Saudi ESL learners. MA thesis. Southern Illinois University, Carbondale, USA.

[7] Centerman, S., \&Krausz, F. (2011). Common L2 pronunciation errors. A degree paper, Malmö University, Sweden.

[8] ------------ (1980). An Introduction to the Pronunciation of English Third Edition. London. Edward Arnold.

[9] Gimson, A. C. 1980. A Practical Course of English Pronunciation. A Perceptual Approach. London: Edward Arnold.

[10] Gut, Ulrike. (2009). Introduction to English Phonetics and Phonology. Textbook in English Language and Linguistics.

[11] Hadroh, Azzatul. (2020). A Study of Pronunciation Error in English Consonant. Journal of English Education And Technology. Vol. 01 No. 03, October 2020, pp. 204-216.

[12] Haryati, Sri (2000).Error pronouncing vowels and consonants by Some Sudents with different gender in Jawa. Malang. Universitas Negeri Malang.

[13] Hyouk-Keun Kim (1999) Interlanguage Phonology of Korean. Korea: International Journal.

[14] Jones, DSpeaker 3el. (2003). English Pronouncing Dictionary. Cambridge: Cambridge University Press.

[15] Ladefoged, Peter. (1982). A Course in Phonetics. New York: Hartcourt Brace Jov Speaker 3c.

[16] Roach, Peter. (1983). English Phonetics and Phonology A Practical Course. Cambridge: Cambridge University Press.

[17] Mathew, Ingrid B. (1997). Errors in pronunciation of consonants by Indonesian, Gayo and Acehnese learners of English as a foreign language.https://ro.ecu.edu.au/theses/904

[18] Mustapha, Muhammad; Ishaku, Nanyisopwa Joyce. (2020). Effects of Ortho-Phonemic Contrasts on The Speeches of Gwandara ESL Speakers. Journal of Languages, Linguistics and Literary Studies (JOLLS). Vol. 9. No. 6 p.90-97

[19] Nguyen, T. T. (2007). Difficulties for Vietnamese when pronouncing English: Final Consonants. A degree paper, Dalarna University, Sweden.

[20] Pasaribu, CiciDwi Kusuma; Kavin, Rakhmad. (2016). Community Assistance in Tarakan the Urban City of North Borneo Province. International Journal of Kybernology. (3)

[21] Rifqi, (2015). An analysis of Madurese interference pronounced by English students from Madura, study in pare Kediri east java.

[22] Sakul, Billy Melvin. (2013). Mispronounced consonants of basic listening and speaking students of UniversitasKlabat. International Conference on Education and Language 2013, UBL, Indonesia. P.97-102

[23] Syuhadi (2014). An analysis of pronunciation error of 6th semester students of English education department of UIN SunanAmpel Surabaya.

[24] Varol, M. (2012). The influence of Turkish sound system on English pronunciation. MA thesis, Florida State University, Tallahassee, FL.

[25] Wafi, Abdul; Ratnawati, Rinta; Ansharul Fuqaha. (2020). Error Analysis on Voicing Sounds Uttered by English Department Students at State Islamic Institute of Madura. PANYONARA: Journal of English Education. Vol. 2, No. 2, September 2020. P.81-96.

[26] Wulansari. (2017). Students' error in pronouncing English vowel sounds: an acoustic analysis across different levels of ability at UIN SunanAmpel Surabaya.

[27] Zajac, David J; Eshghi, Marziye; Bijankhan, Mahmood; Mohsen Shirazi. (2013). Spectral analysis of Wordinitial alveolar and velar plosive produced by Iranian children with cleft lip and palate. Clinical Linguistics \& Phonetics. (3) 